\title{
From the Margins to the Mainstream: Community Restorative Justice in Northern Ireland ${ }^{1}$ Colin Knox
}

Journal of Peacebuilding and Development Vol 8 (2): 2013: 57-72

\begin{abstract}
Biography: Colin Knox is Professor of Comparative Public Policy in the School of Criminology, Politics and Social Policy at the University of Ulster, Northern Ireland. Needed (approx.. 50 words)
\end{abstract}

\section{Key Words: restorative justice, paramilitaries; evaluation; Northern Ireland. Needed (up to ten)}

\begin{abstract}
Paramilitary organisations exerted a stranglehold on working class loyalist and republican communities in Northern Ireland during the conflict. In the absence of an effective and legitimate policing service, paramilitaries developed an alternative 'justice' system in which they 'punished' those accused of committing crimes against the community. They adopted a punitive system of control which included threats or warnings, public humiliation, curfew, exiling, beatings and shootings. This article traces the evolution of this system from illegal paramilitary 'policing' through to restorative justice schemes which, over time, have become a recognised part of the formal criminal justice system. Specifically it examines the role which a series of evaluations had on influencing this transformation. At the very least, policy evaluation informed the political debate and provided evidence to move restorative justice from illegal activities to an integral part of the criminal justice system.
\end{abstract}

\section{Introduction}

This paper traces how illegal practices of paramilitaries groups involved in 'policing' their own communities in Northern Ireland shifted to adopt restorative justice schemes operating in the twilight of the law which were subsequently incorporated into the formal criminal justice system. Specifically it will consider what role evaluations of these schemes played in community restorative justice moving from the margins to the mainstream of criminal justice policy. Three evaluations were conducted over a 10 year period: one by academics, one on behalf of funders (by Professor Harry Mika), and, through the independent statutory criminal justice inspectorate, respectively. The sequencing of the evaluations (see table 2 below) coincided with significant political developments in Northern Ireland: the Belfast (Good Friday) Agreement 1998; periodic suspension and restoration of the devolved Assembly (2000 through 2007); republican endorsement of the policing (2007); and, finally political stability and power sharing (2007 onwards). Evaluation research had the potential to impact either positively or negatively on the wider peace process. Indeed, evidence gathered through the evaluations featured equally in support of how political agreements reached were effective in embedding peace or proved that some political parties were disingenuous about their long term intentions. In short, the paper considers to what extent evaluations of restorative justice were an important evidential contribution element ofto the wider political discourse at a critical juncture in the Northern Ireland peace process. The paper is in three parts: first, the background to, evolution of, the community informal 'justice' system and the transition into regulated restorative schemes; second, the detail of the evaluations which took

\footnotetext{
${ }^{1}$ The author wishes to acknowledge the very helpful comments received on this paper from Kenneth Bush and Colleen Duggan.
} 
place and provided an evidence base for this transition; and third, the intersection of evaluation research and the 'high politics' of Northern Ireland.

\section{Background}

Northern Ireland has witnessed significant changes in its political, constitutional and security landscape since the beginning of the conflict in 1969. Political stability has created an environment where violence is seen by all but the extremists as redundant. The existing political arrangements are rooted in the Belfast (Good Friday) Agreement 1998 that provided for, inter alia, a devolved Northern Ireland Assembly with full executive and legislative authority which has functioned continuously since 2007 after a series of faltering starts. Devolution wavered largely over decommissioning of paramilitary weapons. From its inception in December 1999 until October 2002, the Assembly was suspended four times. A political break-through came in the form of the St Andrews Agreement in October 2006. Following elections, devolved power was restored to the Assembly in May 2007 with a power-sharing Executive headed by Ian Paisley as the Democratic Unionist Party (DUP) First Minister (now replaced by Peter Robinson) and Sinn Féin's Martin McGuinness as Deputy First Minister. A working system of local governance has been in place since 2007, described by the First Minister as the 'most settled period of devolution for over forty years' (Robinson, 2009: 4). An uninterrupted period of devolution, the transfer of policing and justice powers to the Northern Ireland Assembly from Westminster (the so-called final piece of the 'devolution jigsaw'), and a move away from constitutional and security issues heralds a return to 'normal' politics.

Yet political violence cannot be completely discounted even though it has significantly decreased. There is a small but significant level of violence perpetrated by paramilitary groups clinging to the vestiges of control in loyalist and republican working class areas. This community based violence is the focus of this paper. Such was the role played by paramilitaries throughout the conflict in 'policing' their communities that an 'alternative criminal justice system' emerged with its own brutal punitive system of punishing wrongdoers or those accused of committing crimes against their own community.

\section{The evolution of community informal 'justice'}

Informal community 'justice' in contemporary Northern Ireland evolved in the early 1970s within Catholic working class communities where citizen defence committees were set up to protect Catholic enclaves from loyalist attacks. As the security forces (the then Royal Ulster Constabulary - RUC) withdrew from barricaded areas, local defence associations emerged to deal with petty crime within the community. Increasingly, paramilitary organisations became active in policing their own areas. Silke (1998: 124) described the spectrum of punitive actions or 'punishment scale' used. House or shop breakers were compelled to reimburse their victims and return stolen goods. In cases involving children, the IRA approached the parents and requested greater parental control. In situations where an alleged offender refused to co-operate or had ignored previous warnings, they were liable for 'suitable punishment'. This usually involved shooting or beating the individual anywhere in the leg - so-called 'kneecapping' (Republican News, 1971:2). For those 'too young to be kneecapped', 'punishments' included curfew, tar and feathers, being tied up, publicly painted and reprimanding their parents (Republican News, 1982:1). Individuals suspected of informing the police were dealt with most severely and their 'punishment' depended on the type of information passed to the security forces. In some cases they were knee-capped but usually they were shot dead. In loyalist areas, paramilitaries from the early 1970s assumed a similar 
policing role in their communities and used many of the methods adopted by republicans (Smithey, 2011). Although paramilitary groups claimed to carry out investigations into incidents before an individual was punished, effectively they ignored due process, and the human rights of the accused were practically non-existent. Kennedy (1995:14) described the system as a barbaric range of punitive measures against individuals 'who violated some community norm as defined by the paramilitary grouping'. In short, the 1970s to mid 1990s period was characterised as wholly unofficial 'policing' of republican and loyalist communities by paramilitaries in de facto self-governing areas (Knox and Monaghan, 2002).

Political progress and the paramilitary ceasefires in the mid 1990s caused a radical rethink of the informal 'justice' system. No longer could paramilitaries be involved in highly visible acts of violence, particularly against young people, and claim legitimacy in upholding ceasefires. As the political momentum accelerated in the form of the Belfast (Good Friday) Agreement 1998, pressure to loosen the grip of paramilitaries on communities increased. For example, the Agreement $(1998,1: 4)$ outlined its 'opposition to any use or threat of force for any political purpose'. Alternative community 'policing' arrangements were therefore explored. In republican communities, the Northern Ireland Association for the Care and Rehabilitation of Offenders (NIACRO) approached Sinn Féin to investigate ways in which non-violent alternatives might be found to tackle community crime. The model which emerged was based on a system of community restorative justice developed in Canada and the United States in the early 1970s. Community restorative justice has been defined as:

A more inclusive approach to dealing with the effects of the crime, which concentrates on restoring and repairing the relationship between the offender, the victim, and the community at large, and which typically includes reparative elements towards the victim and/or the community (Criminal Justice Review Group, 2000, para. 1)

Loyalists developed a parallel scheme aimed at tackling anti-social behaviour. Both types of community restorative justice schemes, the loyalist Greater Shankill Alternatives Programme (NIA) and the republican Community Restorative Justice Scheme (CRJI) received support funding from Atlantic Philanthropies, an American charitable foundation. These unregulated community restorative justice schemes operated from the late 1990s onwards with some success according to those involved in their operation (Auld et al, 1997; Winston and Watters, 2006).

\section{Regulating restorative justice}

The unregulated community restorative system described above came under both general and legal pressures to adopt government regulation - put starkly, reform or be marginalised. The Belfast (Good Friday) Agreement (1998:22) argued that the police service must be 'capable of winning public confidence and acceptance, delivering a policing service in constructive and inclusive partnerships with the community at all levels, and with maximum delegation of authority and responsibility'. The follow-on political agreement at St Andrews (October 2006) reasserted the need for accountable policing by arguing 'we have consistently said that support for policing and the rule of law should be extended to every part of the community. We believe that all parties share this objective' (Agreement at St Andrews, 2006: section 5). The lack of confidence in policing, particularly in working class areas of Northern Ireland, had been the raison d'être for a parallel (rather than complementary) system of restorative 
justice. As confidence in the PSNI grew and the police gave their support to the principle of restorative justice, albeit with strict conditions, the pressure for change mounted.

There were also legal pressures on the Government to regulate community restorative justice. The Human Rights Act 1998 was received with limited enthusiasm in Northern Ireland but the Belfast (Good Friday) Agreement placed human rights at the centre of the political agenda. The Agreement went much further than the European Convention on Human Rights, recognising that Northern Ireland should be founded on the 'principles of full respect for, and equality of, civil, political, social and cultural rights', as well as 'freedom from discrimination for all citizens' (The Agreement, 1998 para. (v)). There followed two reports detailing how human rights should be implemented in practice. The Patten Report (1999) on policing reforms and the Criminal Justice Review (2000) were extensive documents recognising past institutional failings and recommending how human rights in Northern Ireland might be better protected in the future. Even though these 'additional' measures were not strictly legally binding obligations, the introduction of human rights-friendly policies is both necessary and desirable to translate rhetorical respect into concrete observance (O'Cinneide, 2006). However, it was these two reports (more so the latter) that really thrust community restorative justice onto the political agenda.

\section{The Protocol}

As a result of the recommendations from the Criminal Justice Review, the (then) Minister of State for the Northern Ireland Office, David Hanson, published (after two attempts at consultation) the Protocol for Community-based Restorative Justice Schemes (Northern Ireland Office, 2007). In launching the protocol the Minister emphasised that it contained stringent safeguards to protect the rights of both victim and offenders, and police would be at the centre of the process. He claimed it:

put in place a structure which will provide for effective engagement between communitybased schemes and the criminal justice system in dealing with low level offending. The

high standards set out in the protocol are non-negotiable' (Hanson, 2007: 2).

The protocol followed the precise headings of the Criminal Justice Review recommendations referred to above and included the following principles:

- Schemes must recognise that statutory responsibility for the investigation of crime rests with the police and that the only forum which can determine guilt or innocence, where this is at issue, is a court of law...

- This means that any group or structures organised by the community should include provision for full co-operation and communication with the police. (Northern Ireland Office, 2007)

Not surprisingly, republican communities found this protocol totally unacceptable. The role of the police was central to reporting, investigating and applying sanctions at the community level. For republicans, at that time, this was simply unworkable. The police, on the other hand, argued that they needed to know the nature of the crime, who the offender is, and that (s)he is being dealt with by the scheme. If not, the offender is left open to double jeopardy. Acutely aware, however, of the need to satisfy standards by which its schemes should operate, republicans (drawing on previous research) developed their own code of practice, setting standards pertaining to participants, the community, and outlining fundamental concepts of restorative justice, without reference to the police in their documentation (Community Restorative Justice, 1999). The Northern Ireland Office protocol included an 
accreditation process whereby each community-based restorative justice scheme had to confirm to the Criminal Justice Inspection (CJI), an independent statutory body with responsibility for inspecting all aspects of the criminal justice system in Northern Ireland (apart from the judiciary), its willingness to adhere to the protocol. If, after inspection, the Inspectorate was satisfied that the standards set out in the protocol were being met, the scheme became accredited by the Northern Ireland Office. Schemes which received accreditation became eligible for government resources (the carrot); those schemes which did not apply or were turned down did not receive government funding nor engage formally with the criminal justice system (the stick). The latter could continue with their unregulated work and, providing they did nothing illegal, the Government was in no position to discontinue their work.

\section{From the margins to the mainstream}

The loyalist Northern Ireland Alternatives and its four restorative schemes were the subject of an inspection with a view to accreditation from the Criminal Justice Inspectorate Northern Ireland in April 2007. The report noted the role played by the schemes in reducing 'punishment' beatings by offering alternative means of dealing with low-level offending: 'the schemes... first and foremost are a community resource dedicated to working with difficult youngsters, either diverting them away from crime in the first place or helping them to draw them out of criminal and anti-social behaviour..' (Criminal Justice Inspection, 2007a: 18, 3.6).

The report concluded that the loyalist schemes 'worked to a high standard with difficult young people in their communities' and recommended that Northern Ireland Alternatives be accredited, subject to agreement on conditions identified by the Inspection team. The first schemes to be accredited were: the loyalist Northern Ireland Alternatives, Greater Shankill Alternatives, East Belfast Alternatives, and North Belfast Alternatives.

In October 2007, Criminal Justice Inspection completed a pre-inspection report of republican schemes in Belfast and Derry/Londonderry which operate under the auspices of Community Restorative Justice Ireland (CRJI), the first stage of the accreditation process. Their involvement in this initial process was significant and was helped by the fact that in January 2007 Sinn Féin publicly recognised the Police Service of Northern Ireland (PSNI). The report covered two sets of CRJI schemes - four in Derry and four in West Belfast and essentially described the state of readiness of the schemes for accreditation. The inspectors concluded:'the fact that, for historical reasons, the schemes do not normally pass information to the police means that they are not at present operating in accordance with the Protocol. (Criminal Justice Inspection, 2007b: 31, 5.2). The report recommended that the CRJI schemes should be considered for accreditation as soon as they were ready to declare that they were complying with the Protocol, and set out several suggestions as to how they might do this.

In June 2008 the Criminal Justice Inspectorate re-inspected the republican restorative justice schemes and based on a balance between 'risks and opportunities involved', they confirmed accreditation (Criminal Justice Inspection Northern Ireland, 2008: 13). The risks were of the schemes behaving improperly, and the opportunities were establishing a proper relationship with the police and helping them to reach out to communities which were alienated and poorly served. In accrediting the schemes the Inspectorate noted that they needed to be closely monitored and a fully independent complaints mechanism put in place. In a follow-up 
report conducted by the Inspectorate in 2011, CRJI was criticised for their complaints policy and not meeting the threshold for inclusion under the Government's Protocol for communitybased restorative justice. However, the report concluded that:

The schemes are increasingly assuming a role where they are attempting to influence dissident republican paramilitaries and other armed groups away from intimidation, expulsions and violence. This work is valued particularly by the police, local community and some political leadership and is seen as an important element in ensuring that these events do not become commonplace (Criminal Justice Inspection, 2011: 19, 5.7).

The transformative nature of the fully accredited schemes operated through CRJI and NIA is now recognised by most statutory agencies on the ground. The schemes are involved in the delivery of services ranging from community and mediation support, counselling and youth work, to interventions in cases of anti-social behaviour and those 'under threat'. The schemes receive financial support from a range of statutory and philanthropic funders, all of which express a high level of satisfaction with the services they provide (Knox, 2011). The statutory organisations include: the Department of Justice, Department for Social Development, Probation Board for Northern Ireland, PSNI, Northern Ireland Housing Executive, and the Belfast Health Trust.

This paper summarises the key stages in the transition of restorative justice schemes from the margins to the mainstream in table 1 below.

Table 1: Community-based restorative justice schemes - the transition

\begin{tabular}{|c|c|c|}
\hline [1970 - mid 1990s] & $\begin{array}{c}\text { Unregulated } \\
\text { Community Restorative } \\
\text { Justice } \\
{[1994-2006]} \\
\end{array}$ & $\begin{array}{l}\text { ulated Community Restorative } \\
\text { Justice } \\
\text { [2007 onwards] }\end{array}$ \\
\hline $\begin{array}{l}\text { - Absence of } \\
\text { legitimate } \\
\text { policing service in } \\
\text { loyalist and } \\
\text { republican areas } \\
\text { - Paramilitary } \\
\text { organisations } \\
\text { 'police' their own } \\
\text { communities } \\
\text { Tariff system of } \\
\text { 'punishment' } \\
\text { operates } \\
\text { Due process } \\
\text { ignored and no } \\
\text { protection for } \\
\text { rights of alleged } \\
\text { perpetrators }\end{array}$ & $\begin{array}{l}\text { - Non-violent } \\
\text { alternative schemes } \\
\text { set up: Northern } \\
\text { Ireland Alternatives } \\
\text { (loyalist) and } \\
\text { Community } \\
\text { Restorative Justice } \\
\text { (republican) } \\
\text { - Schemes operate } \\
\text { outside } \\
\text { government/police } \\
\text { control } \\
\text { Loyalists 'co-operate' } \\
\text { with police; } \\
\text { republicans eschew } \\
\text { RUC/PSNI } \\
\text { Schemes funded by } \\
\text { philanthropic sources }\end{array}$ & $\begin{array}{l}\text { Government produces protocol } \\
\text { (2007) to accredit community based } \\
\text { schemes } \\
\text { - New regulated schemes can deal } \\
\text { only with low level offences referred } \\
\text { to them by Public Prosecution } \\
\text { Service } \\
\text { - Schemes required to operate in } \\
\text { accordance with the Human Rights } \\
\text { Act } 1998 \text { \& UN Convention on the } \\
\text { Rights of the Child in their } \\
\text { interaction with young victims and } \\
\text { offenders. } \\
\text { - NIA and CRJI receive accreditation } \\
\text { (2007 and 2008, respectively) from } \\
\text { Criminal Justice Inspection. } \\
\text { - Schemes provide restorative services } \\
\text { to a range of statutory organisations }\end{array}$ \\
\hline
\end{tabular}

\section{Evaluation of the schemes}


Given the journey of the restorative justice schemes, from operating as illegal activities directed by paramilitaries to becoming an integral element in the formal criminal justice system, a key question in this paper is the extent to which formal evaluation and evidence therein played a part in this process. Evaluation research, according to Rossi and Freeman (1993: 5), is 'the systematic application of social research procedures for assessing the conceptualisation, design, implementation and utility of social intervention programs.' There were three evaluations conducted during the transition from illegal practices to mainstream restorative justice which were very different in focus and type. The first evaluation, using taxonomy developed by Patton, might be described as a responsive evaluation which sought to capture, represent and interpret varying perspectives, in particular why communities 'accepted' domination by paramilitary groups and why government was prepared to turn 'a blind eye' to this practice (Patton, 2008; Stake and Abma, 2005). The second evaluation can be understood as an impact evaluation which considered the outcomes of community restorative models on victims and perpetrators and whether this type of intervention was an effective way of tackling low level crime and anti-social behaviour. The third evaluation is depicted as having a compliance focus - were restorative justice schemes acting in accordance with human rights principles and criminal justice protocol arrangements? We now consider each of these in some detail.

\section{Academic research (responsive evaluation)}

The first project, entitled An Evaluation of the Alternative Criminal Justice System in Northern Ireland, was conducted by academics and funded by the respected and independent Economic and Social Research Council (ESRC) in the UK. The overall aim of the research was to contribute to an understanding of increasing paramilitary influence in 'policing' the two communities in Northern Ireland and the concomitant threat to social stability. The research took place from 1998 - 2000 and involved significant primary data collection -42 interviews with victims, 2 with perpetrators, 6 focus groups with key stakeholders including the police and probation services, 12 politicians and 80 statutory and voluntary/NGO organisations in Northern Ireland. In addition, 2 large excel databases of reported paramilitary-style attacks were constructed and GIS maps of locations drawn.

The timing of the evaluation is significant because it straddled important political events. The Belfast (Good Friday) Agreement was signed on 10 ${ }^{\text {th }}$ April 1998 following which power was devolved from Westminster to the Northern Ireland Assembly on $2^{\text {nd }}$ December 1999. During the negotiations in the run up to the Agreement all parties involved had to endorse the Mitchell principles of democracy and non-violence. One principle urged that 'punishment' killings and beatings stop and parties take effective steps to prevent such actions. The negotiators noted: 'We join the governments, religious leaders and many others in condemning 'punishment' killings and beatings.' (Mitchell, de Chastelain and Holkeri, 1996: paragraph 20).

The outcome of the multi-party talks was the Belfast (Good Friday) Agreement 1998 in which all participants reaffirmed their 'total and absolute commitment to exclusively democratic and peaceful means of resolving differences on political issues, and our opposition to any threat of force by others for any political purpose' (Belfast [Good Friday] Agreement: section 4:1, 1998). Over nineteen months later, in advance of devolution, Sinn Féin stated the importance of the political process in making conflict a thing of the past and emphasised their opposition to the use of force and 'punishment' attacks (Sinn Féin statement: 16 November 1999). 
The findings of the evaluation were damning in the extreme. The researchers found that victims of paramilitary 'punishment' beatings and shootings had become expendable and legitimate targets for violence in Northern Ireland. They were expendable in the sense that any attempt to deal with this problem in a serious way would have widespread political ramifications for parties currently in devolved government. The Mitchell principles of 'democracy and non-violence' which were pivotal to the Belfast (Good Friday) Agreement could not be upheld. It appears that it was political expedient to turn a blind eye to these acts of brutality. They were legitimate in the sense that the victims' culpability derived from the communities within which they lived and their 'punishment' was meted out by paramilitaries acting on the communities' behalf. Both these factors conspired to make this group not only the forgotten victims of violence in Northern Ireland, but arguably the most vulnerable. The researchers described this as a 'see no evil, hear no evil' reaction on the part of the British Government given the fragility of the peace process (Knox, 2002). The Government's response was that one must accept certain violent excesses in the interests of moving forward politically. This justification appears in the lexicon of political debate on Northern Ireland at the time. The former Secretary of State (Mo Mowlam, 1999: 2) suggested 'the peace we have now is imperfect, but better than none' or perhaps, more tersely, as having 'an acceptable level of violence'.

The research also became the subject of two parliamentary debates. In the House of Commons the Conservative Party attempted to halt the early release of political prisoners under the terms of the Belfast (Good Friday) Agreement because of continuing paramilitarystyle shootings and beatings (Hansard, Official Report, 1999). In a Northern Ireland Assembly debate, pro- and anti-Agreement politicians adopted contrasting positions on the ESRC evaluation findings. One pro-Agreement party argued that the report 'highlighted the strong support that there is for alternatives to 'punishment' attacks (such as restorative justice) in the absence of a legitimate policing service' (Gildernew, 2001:361). AntiAgreement parties claimed that paramilitary attacks had soared as a direct result of prisoner releases and the research 'presented cogent evidence that the Good Friday Agreement is failing' (Paisley, 2001: 366). Politicisation was an ongoing feature of the debate on the issue. The (then) Sinn Féin Health Minister, Bairbre de Brun, was regularly asked for information in the Northern Ireland Assembly on how the immediate hospitalisation of those subject to beatings and shootings was displacing patients on long waiting lists in need of orthopaedic surgery and trauma counselling (Hansard, Official Report, 2001). This was as much intended to embarrass and undermine the Sinn Féin Minister as it was to highlight the plight of paramilitary victims.

\section{The Funder's evaluation (impact evaluation)}

The second evaluation was commissioned by the external funder (Atlantic Philanthropies) of the restorative justice schemes, Northern Ireland Alternatives and Community Restorative Justice Ireland. It was conducted by Professor Harry Mika, an international expert on restorative justice, from Central Michigan University, USA and the Institute of Criminology and Criminal Justice in Queen's University, Belfast. Mika's primary research involved the analysis of 500 formal case interventions and 'several hundred interviews' over the period between 1999 and 2005.

The findings of the evaluation concluded, inter alia, the following: 
- The restorative justice programmes prevented nearly 500 cases of paramilitary beatings and shootings. NIA and CRJI caused a significant drop in the number of beatings and shootings compared to neighbourhood areas outside their catchment population.

- The acceptance of community restorative justice solutions by armed groups increased significantly.

- Community leaders felt that the projects had become essential community assets.

- Potential limitations of NIA and CRJI were caused by: perceived paramilitary links, political criticism, inadequate resourcing and increasing demands for their services (Mika, 2007: 33-34).

Mika's evaluation was a very strong endorsement of the community restorative justice schemes and also coincided with a series of political events which created the context for a more receptive response than the ESRC evaluation. The Northern Ireland Assembly had been faltering since its inception in 1999 and was dissolved by the British Government in October 2002. The two issues of central concern which formed the basis of talks to achieve restoration of the political institutions were: the need to support policing and the rule of law across the whole community and eventually the devolution of policing and justice, and support for power-sharing and the political institutions. The British and Irish Government reached agreement on these issues as set out in the St Andrews Agreement of $13^{\text {th }}$ October 2006, the details of which were given legislative effect in the Northern Ireland (St Andrews Agreement) Act 2006. The Act made provisions for a new transitional Assembly, set out a timetable to restore devolution, the date for the third election to the Northern Ireland Assembly, and made important amendments to the Northern Ireland Act 1998 which came into force with the restoration of devolved government on $8^{\text {th }}$ May 2007. Ian Paisley (then DUP leader) and Gerry Adams (the leader of Sinn Féin) agreed to establish a power sharing Executive which has been in operation since then. Very quickly thereafter Sinn Féin joined the Northern Ireland Policing Board (June 2007) for the first time since it was established in 2001. The role of the board is to hold the PSNI to account through the Chief Constable for the delivery of effective and impartial policing.

Sinn Féin's members had backed their leadership's proposal to get involved in policing on the condition that a power sharing Executive was established. With power sharing in place and Sinn Féin participating in the Policing Board, there was no reason why restorative justice schemes in republican areas should not be co-operating fully with the PSNI, one of the key stumbling blocks to the accreditation process. The political choreography continued when Community Restorative Justice Ireland wrote to the Minister of State for Northern Ireland in February 2007 seeking accreditation in respect of their restorative justice schemes in Belfast and Derry/Londonderry. In short, Mika's evaluation findings coincided precisely at a time when political developments were wholly positive towards a response to republican overtures on policing and security, including their role in restorative justice schemes. The accreditation process by the Criminal Justice Inspection was to copper-fasten republican commitments to community restorative justice.

\section{Criminal Justice Inspection reports (compliance evaluation)}

The inspection reports of the Criminal Justice Inspection Northern Ireland were key documents in moving restorative justice schemes from the margins to the mainstream of the criminal justice system. The loyalist Northern Ireland Alternatives schemes were quick to avail of the opportunity to achieve formal accreditation given their ongoing co-operation with 
the PSNI and sought an inspection in March 2007. The methodology used by the inspectors was to gather both primary and secondary research data. They read extensive documentation: case files, policy documents, training materials, management committee minutes and annual reports and accounts. They also interviewed staff and volunteers, clients of the schemes (both young offenders and victims), parents of the children participating in the schemes and a wide range of other interested parties, including local politicians, PSNI officers, Probation officers and school teachers with experience of working with the schemes.

Fears that community-based restorative justice schemes were a front for paramilitary organisations or that people were forced into taking part in restorative justice by paramilitaries were addressed in the course of the inspections by CJI. The inspectors found no evidence that there was any such problem in relation to Northern Ireland Alternatives or its schemes. In addition, there was no evidence of the schemes being driven by paramilitaries and every indication to the contrary. The report concluded that Alternatives 'did not provide an alternative policing or judicial system. Most of the work undertaken by the schemes relates to community development' (Criminal Justice Inspection, 2007a). The inspectors supported accreditation. A follow-up report was conducted by CJI in February 2010 and endorsed the earlier positive evaluation. The inspectors concluded that they 'had heard unanimous support for the work of NIA and the contribution the organisation was making in helping the lives of people living within some of the most socially deprived loyalist areas of Greater Belfast and North Down'. As a result of NIA's willingness to engage with statutory agencies they had earned 'real respect and a desire to increase the level of partnership working' (Criminal Justice Inspection, 2010: 14).

Republican restorative schemes have struggled with the accreditation process and failed to achieve the same recognition as Northern Ireland Alternatives. A pre-inspection report conducted by CJI in May 2007 found that although the republican schemes were engaged in work that was valued by their communities, there were improvements that needed to be made before the schemes would be ready for accreditation (e.g. staff training to work to the standard required by the Protocol and to improve their record-keeping and the secure storage of files). A further inspection took place in June 2008 to determine Community Restorative Justice Ireland's accreditation status. The inspectors found that the schemes were operating lawfully and non-coercively, were respecting human rights, and were beginning to develop a constructive relationship with the PSNI. All 10 schemes operated by CRJI were accredited as a result (July 2008). However, in a follow-up inspection involving an examination of case files, CJI found that since securing accreditation, only one case had been referred by CRJI to the PSNI under the Government Protocol which highlighted a need for the current Protocol to be reviewed. Despite this, the inspectors found a number of positive developments had occurred in the three years since its previous inspection. 'CRJI has become an important part of the voluntary and community sector landscape in parts of Northern Ireland and are integrating their activities as part of local community safety networks' (Criminal Justice Inspection, 2011:13).

\section{Conclusions}

It is clear that the political context in Northern Ireland has improved significantly and, with that, restorative justice schemes have moved from their original mission of providing an alternative option for young people who 'came to the attention' of paramilitaries because of anti-social behaviour. Schemes now work in partnership with many statutory organisations using their restorative practice skills in other public policy areas where mediation is required (e.g. education and neighbourhood disputes). What is also clear is that as political stability 
has become embedded, mutilations, torture, beatings and exiling can no longer come within the purview of an 'acceptable level of violence' or be seen as part of the imperfections of the peace process. The inspections/evaluations conducted by Criminal Justice Inspection have played an important part in 'normalising' restorative justice schemes. The 'risks and opportunities' calculus which they use - schemes breaching human rights of offenders versus the potential for republicans and loyalists to work in partnership with the police, has paid off. All three evaluations demonstrate the inextricable link between the changing political context and efforts to mainstream community restorative justice. Evidence from the ESRC evaluation became part of the vitriolic pro- and anti-Agreement debate. Mika's evaluation coincided with a period of political consensus on policing and power sharing. And the Criminal Justice Inspection reports ushered restorative justice schemes from the margins into mainstream criminal justice policy. However, the direction of the influence is unclear here. Did the evaluations offer valuable empirical evidence at critical junctures in the political process, or did improving peace-building efforts allow a much more conducive environment in which restorative schemes flourished?

There is also the question as to whether the nature of the evaluations was important to the influence which they had? The ESRC study or responsive evaluation (to return to Patton's taxonomy above) conducted by academics presented independent evidence regardless of its impact on the fragile political environment. This evaluation offered an in-depth analysis of key stakeholders in the process - paramilitaries, police, victims, and government. It challenged the NI Secretary of State to confront the contradictions of an 'acceptable level of violence'. The potential impact of this evaluation was limited by the politicisation of its findings but it provided important evidence as to why communities 'accepted' paramilitaries as guarantors of local justice. The funders' or impact evaluation (in Patton's terms) was straightforwardly an attempt to assess whether externally supported interventions were an effective alternative way of dealing with a repressive 'justice' regime. The strength of this study was the duration of the research which allowed evaluators to capture change over time and affirm NGOs as recognised mediators in the restorative process. Its findings were timely in that they coincided with a period when working with the police became consistent with the wider republican political agenda. In other words, there is evidence that restorative justice works and the question became how best to mainstream an externally funded intervention. The Criminal Justice Inspection reports or compliance evaluation (in Patton's taxonomy) became a passport to government funding and legitimacy with other statutory organisations because they offered evidence of restorative justice schemes complying with international human rights standards which respected due legal process and the rights of the victims and perpetrators. Given the source of these reports and the weight which they carried as a consequence, it seems likely that they were pivotal to the success of incorporating restorative justice as part of the formal criminal justice system. Collectively, therefore, evaluation research: shone a light on the illegal activities of paramilitaries in 'policing' their communities and the acquiescence of the police and government in this process; provided evidence of an effective alternative administered through local NGOs with experience in restorative justice; and, demonstrated how restorative schemes could provide services which were fully-compliant with the law and human rights standards. We summarise the three evaluations of restorative justice schemes in Northern Ireland and their intersection with the 'high politics' of Northern Ireland in table 2. 
Table 2: The intersection of evaluation and political context

\begin{tabular}{|c|c|}
\hline $\begin{array}{l}\text { Evaluation of restorative justice in } \\
\text { Northern Ireland }\end{array}$ & Political context \\
\hline $\begin{array}{l}\text { Funder: Economic and Research Council } \\
\text { (ESRC) } \\
\text { Dates: 1998-2000 } \\
\text { Methods: Interviews with victims, } \\
\text { perpetrators, politicians, NGOs, police, } \\
\text { probation board. Construction of data base to } \\
\text { understand nature and incidence of beatings } \\
\text { and shootings }\end{array}$ & $\begin{array}{l}\text { Fragile political talks leading up to the } \\
\text { Belfast (Good Friday) Agreement. } \\
\text { Involvement in paramilitary-style attacks } \\
\text { could have excluded loyalist and } \\
\text { republican parties from peace talks and } \\
\text { political agreement. } \\
\text { British Government adopts 'see no evil, } \\
\text { hear no evil' approach to community } \\
\text { violence - bigger prize stance. }\end{array}$ \\
\hline $\begin{array}{l}\text { Funder: Atlantic Philanthropies (external } \\
\text { funder of restorative justice interventions) } \\
\text { Dates: } 1999-2005 . \text { Evaluation published } \\
\text { January } 2007 \\
\text { Methods: Extensive review of case files, } \\
\text { large number of interviews with key } \\
\text { stakeholders, and non-participant observation } \\
\text { techniques. }\end{array}$ & $\begin{array}{l}\text { Devolved government in place since } \\
\text { 1999, although ongoing suspensions of } \\
\text { the institutions. } \\
\text { - St Andrews Agreement (2006) secures } \\
\text { Sinn Féin support for policing and } \\
\text { political deal on power-sharing } \\
\text { arrangements. } \\
\text { - Wider political imprimatur allows } \\
\text { republican restorative justice schemes to } \\
\text { work with police. }\end{array}$ \\
\hline $\begin{array}{l}\text { Funder: Criminal Justice Inspection - non- } \\
\text { departmental public body and independent } \\
\text { statutory inspectorate funded from the public } \\
\text { purse (formerly located in the Northern } \\
\text { Ireland Office and now in the devolved } \\
\text { Department of Justice). } \\
\text { Dates: } 2007 \text { - onwards } \\
\text { Methods: Evaluation inspections and follow- } \\
\text { up reports using case files, organisational } \\
\text { documentation, and extensive interviews } \\
\text { with key stakeholders }\end{array}$ & $\begin{array}{l}\text { Much improved political milieu - power } \\
\text { sharing Executive and Assembly fully } \\
\text { operational. } \\
\text { - Active encouragement by Criminal } \\
\text { Justice Inspection for restorative justice } \\
\text { schemes to adopt protocol principles. } \\
\text { - Restorative justice schemes refocus their } \\
\text { work towards community mediation with } \\
\text { a large number of statutory organisations. } \\
\text { Restorative justice mainstreamed and an } \\
\text { integral part of formal criminal justice } \\
\text { system. }\end{array}$ \\
\hline
\end{tabular}

Can we be definitive about the impact of restorative justice schemes? Looking at the statistics since 1982 categorised as paramilitary-style shootings and beatings, some patterns emerge. Figure 1 shows the combined figures for beatings and shootings by republican and loyalist paramilitaries over time (PSNI, 2012). 


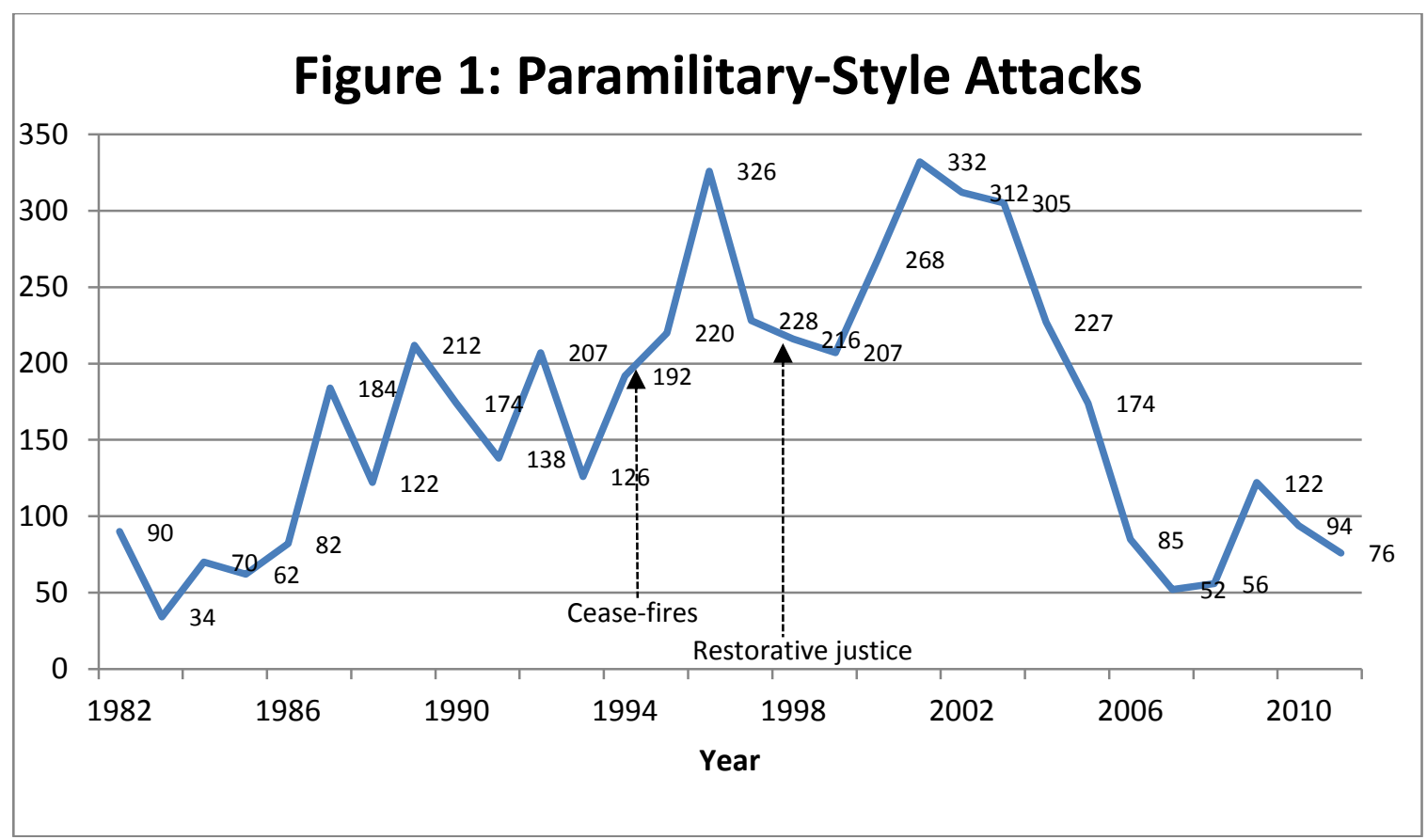

The paramilitary cease-fires of August and October 1994 witnessed a significant decrease in the number shootings to the lowest recorded level, but beatings simultaneously increased to their highest recorded level, hence the spike in figure 1. This was a technical cop-out by paramilitaries who could claim they were not breaking the conditions of the cease-fires instead of shooting those involved in anti-social behaviour, they beat them. The introduction of restorative justice programmes seemed to have had a short term effect on the overall level of paramilitary attacks but numbers increased to the highest recorded levels in 2001. During that period, wider political developments in the peace process were in trouble. The Northern Ireland Assembly was indefinitely suspended in October 2002 for the fourth time since devolution (December 1999) due to 'a lack of trust and loss of confidence on both sides of the community' according to the Secretary of State (Reid, 2002: 201). This stemmed from concerns about Sinn Féin's commitment to exclusively democratic and non-violent means and accusations by each community of the other that they did not endorse the full operation and implementation of the Belfast (Good Friday) Agreement. A climate of mistrust and uncertainty prevailed accentuated by events such as the trial of republicans in Colombia (allegedly involved in training the left-wing FARC group, Revolutionary Armed Forces of Colombia), but subsequently found not guilty), the break-in at Special Branch offices in Castlereagh Police Station (where personal details of Special Branch detectives were removed), and political espionage at Stormont implicating Sinn Féin. In the latter, unionists accused the IRA of exploiting Sinn Féin's membership of the Executive to gather information (names and addresses of prison officers) of use in future acts of violence. Since then, the trend has been downwards although the problem has not been eradicated because loyalist paramilitaries now involved in drug-dealing resort to their old punitive tactics.

Have the restorative justice schemes contributed to the downward trend in paramilitary-style attacks? There are limitations in assessing impact through examining the statistics, not least because of our inability to isolate cause and effect variables in the restorative justice schemes and establishing the counterfactual position - in the absence of the schemes, beatings and shootings could have been a lot higher. The level of 'punishment' attacks may have little to do with what happens within the restorative schemes but influenced by extraneous factors over which they have no control. The loyalist turf feud between factional paramilitary groups 
in the Shankill (Belfast) in 2000, for example, probably resulted in a number of 'housekeeping' attacks by paramilitaries. Developments in the wider political landscape such as police reforms and the changes in the criminal justice system have impacted on the continuance or otherwise of 'punishment' attacks. It is also unrealistic to expect restorative justice schemes in isolation to tackle the systemic causes of anti-social behaviour: poverty, unemployment, urban decay and the wider social, political and economic milieu in which community violence exists. Disentangling the evidence emerging from evaluations of restorative justice schemes in a context of significant political reform is problematic. Proving a cause and effect relationship on declining paramilitary-style attacks is equally difficult. At the very least, policy evaluations of the schemes informed the political debate and, by design or default, provided timely evidence which helped to move restorative justice from illegal activities which paramilitaries used to exert control in working class communities to an integral part of the criminal justice system. 


\section{References}

Agreement at St Andrews (2006). Belfast: Northern Ireland Office.

Auld, J., Gormally, B., McEvoy, K., and Ritchie, M. (1997) Designing a System of Restorative Justice in Northern Ireland: a discussion document. Belfast: Institute of Criminology and Criminal Justice, Queen's University.

Community Restorative Justice (1999) Standards and Values of Community Restorative Justice. Belfast: CRJ.

Criminal Justice Inspection Northern Ireland (2007a) Northern Ireland Alternatives. Report of an inspection with a view to accreditation under the Government's Protocol for Community Based Restorative Justice. Belfast: CJI.

Criminal Justice Inspection Northern Ireland (2007b) Community Restorative Justice Ireland: Report of a pre-inspection of schemes in Belfast and in the North West with a view to accreditation under the Government's Protocol for Community Based Restorative Justice. Belfast: CJI.

Criminal Justice Inspection Northern Ireland (2008) Community Restorative Justice Ireland: Report of an Inspection. Belfast: CJI.

Criminal Justice Inspection Northern Ireland (2010): A follow-up review of the Community Restorative Justice Schemes operated by Northern Ireland Alternatives. Belfast: CJI.

Criminal Justice Inspection Northern Ireland (2011) Community Restorative Justice Ireland: A follow-up review of the Community Restorative Justice Ireland community restorative justice schemes. Belfast: CJI

Criminal Justice Review Group (2000) Review of the Criminal Justice System in Northern Ireland paragraph 1. London: The Stationery Office.

Gildernew, M. (2001) Northern Ireland Assembly Debate, Punishment Beatings, Hansard, Official Report, $23^{\text {rd }}$ January: 356-70.

Hansard, Official Report (1999), Terrorist Mutilations (Northern Ireland): 347-398. House of Commons Debate $27^{\text {th }}$ January.

Hansard, Official Report (2001), Northern Ireland Assembly Debate, Paramilitary Activity and Hospital Waiting Lists $18^{\text {th }}$ September: 201-240.

Hanson, D. (2007) 'Stringent safeguards in new CRJ protocols' News Release Northern Ireland Office: $5^{\text {th }}$ February.

Kennedy, L. (1995) 'Nightmares within nightmares: paramilitary repression within workingclass communities' in L. Kennedy (ed.) Crime and Punishment in West Belfast. Belfast: Summer School, West Belfast. 
Knox, C. (2002) 'See no evil, hear no evil': Insidious paramilitary violence in Northern Ireland, The British Journal of Criminology, 42 (1): 164 - 185.

Knox, C. and Monaghan, R. (2002) Informal Justice in Divided Societies: Northern Ireland and South Africa. Basingstoke: Palgrave Macmillan.

Knox, C. (2011) Community Based Restorative Practice Schemes: a review of funding arrangements. Belfast: Atlantic Philanthropies.

Mika, H. (2007) Community-Based Restorative Justice in Northern Ireland. Queen's University Belfast.

Mitchell, G., de Chastelain, J. and Holkeri, H. (1996) Report of the International Body on Arms Decommissioning. Belfast: Northern Ireland Office.

Mowlam, M. Secretary of State's judgement on alleged breach of cease-fire. Northern Ireland Office, 27 August 1999.

Northern Ireland Office (2007) Protocol for Community-based Restorative Justice Schemes, $5^{\text {th }}$ February. Belfast: Northern Ireland Office.

O’Cinneide, C. (2006) 'Equivalence in Promoting Equality' available at www.equality.ie

Paisley, I. (2001) Northern Ireland Assembly Debate, Punishment Beatings, Hansard, Official Report, $23^{\text {rd }}$ January: 356-70.

Patten Report (1999) A New Beginning: Policing in Northern Ireland: Report of the Independent Commission on Policing in Northern Ireland. Belfast: Stationery Office.

Patton, M.Q. (2008) Utilization-Focused Evaluation, $4^{\text {th }}$ Edition. London: Sage.

Police Service of Northern Ireland: Police Service of Northern Ireland statistics available at: http://www.psni.police.uk/index/updates/updates_statistics.htm accessed $15^{\text {th }}$ October 2012.

Reid, J. (2002) Statement by the Secretary of State for Northern Ireland to the House of Commons, Hansard, Official Report, $15^{\text {th }}$ October.

Republican News (1971) An Phoblacht 'Why Tar and Feathers?' 20 ${ }^{\text {th }}$ February: 2.

Republican News (1982) An Phoblacht 'Punishment Shootings'. Republican News $25^{\text {th }}$ March: 1.

Robinson, P. (2009) 'Making devolution work' speech by Peter Robinson at Ulster Hall, Belfast, $8^{\text {th }}$ September.

Rossi, P.H. and Freeman, H.E. (1993) Evaluation: A Systematic Approach, $5^{\text {th }}$ edition. London: Sage Publications.

Silke, A. (1998) 'The Lords of Discipline: the methods and motives of paramilitary vigilantism in Northern Ireland' Low Intensity Conflict and Law Enforcement 7(2): 121-156. 
Smithey, L. (2011) Unionists, Loyalists, and Conflict Transformation in Northern Ireland. Oxford: Oxford University Press.

Stake, R. and Abma, T. (2005) 'Responsive Evaluation' in S. Mathison (ed.) Encyclopaedia of Evaluation: 376-79. London: Sage.

The Agreement (1998) Agreement Reached in Multi-Party Negotiations. Belfast: Northern Ireland Office.

Winston, T. and Watters, D. (2006) Evidence given to the Northern Ireland Affairs Committee Draft Protocol for Community-based Restorative Justice Schemes. Hansard, Official Report, HC 87: 37-46. 